\title{
Dipyridamole increases the cytotoxicity of cisplatin in human larynx cancer cells in vitro
}

M. Rodrigues ${ }^{1}$,

F. Barbosa Junior ${ }^{2}$ and J.R. Perussi ${ }^{1}$

\author{
'Departamento de Química e Física Molecular, Instituto de Química de São Carlos, \\ Universidade de São Paulo, São Carlos, SP, Brasil \\ ${ }^{2}$ Cena, Universidade de São Paulo, Piracicaba, SP, Brasil
}

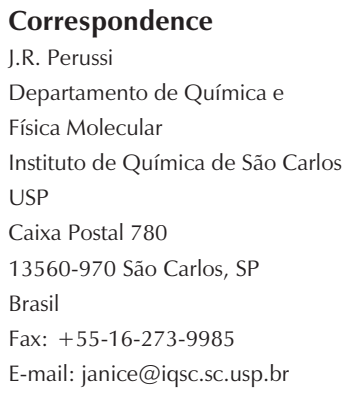

Received June 9, 2003 Accepted January 27, 2004

\begin{abstract}
This paper describes the effect of dipyridamole (DIP) on the cytotoxicity of cisplatin in HEp-2 human larynx cancer cells in vitro and the nature of the interaction between cisplatin and dipyridamole. Cytotoxic assays were performed to obtain the $\mathrm{IC}_{50}$ for cisplatin. The cells were treated with $0,20,40,80,120$ or $200 \mu \mathrm{M}$ cisplatin, with or without a single concentration of DIP and incubated for $60 \mathrm{~min}$ at $37^{\circ} \mathrm{C}$ and $5 \% \mathrm{CO}_{2}$ for 3 days and then counted with a hemocytometer. The accumulation of cisplatin in the cells was measured by atomic absorption and fluorescence was used to determine the membrane binding constant of DIP. In the presence of 10,20 and $30 \mu \mathrm{M}$ DIP, the $\mathrm{IC}_{50}$ of cisplatin was reduced by 25,60 and $82 \%$ in HEp- 2 cells. Combination index analysis revealed that cisplatin and DIP interact synergistically. In larynx cancer cells, the accumulation of cisplatin increased by 13 , 27 and $65 \%$ as the DIP concentration was increased from 10 to 20 and $30 \mu \mathrm{M}$, respectively. The binding constant of DIP to the cell membrane was estimated to be $(0.36 \pm 0.12 \mathrm{mg} / \mathrm{ml})^{-1}(\mathrm{~N}=2)$ by fluorescence and cisplatin did not suppress DIP fluorescence. These results suggest that DIP significantly enhances cisplatin cytotoxicity in HEp2 cells by increasing cisplatin accumulation, probably by altering the cell membrane as suggested by its binding constant. The results obtained reinforce the importance of combination therapy to reduce the doses of chemotherapeutic drugs and therefore the side effects of chemotherapy.
\end{abstract}

Key words

- Cisplatin

- Dipyridamole

- Synergism

- Tumor cells

- Cytotoxicity

- $\mathrm{IC}_{50}$

\section{Introduction}

Cisplatin has been used to treat different kinds of cancer although toxic side effects are known (1). The antitumor activity of cisplatin involves induction of intra- and interstrand cross-links that severely distort the DNA helix and block replication (1-3). Since cisplatin accumulation is a major de- terminant of its antitumor activity, modulators of cisplatin accumulation have received much attention.

Dipyridamole (DIP) has been used clinically in coronary heart disease for its antiplatelet and vasodilating activities $(4,5)$ and is best known as an inhibitor of membrane nucleoside transport (6). DIP increases the cytotoxicity of several anti-cancer drugs in- 
cluding 5-fluorouracil (7), methotrexate $(8,9)$, adriamycin (10), etoposide (11), doxorubicin and vinblastine (12), and cisplatin (13). Jekunen et al. (13) showed that DIP synergistically enhanced the cytotoxicity of cisplatin in cisplatin-sensitive 2008 human ovarian carcinoma cells by a factor of 4.7 , and in the cisplatin-resistant $2008 / \mathrm{C} 13 * 5.25$ subline by a factor of 5.8. In a nude mouse model with human bladder cancer (14), tumor size decreased by $20 \%$ when cisplatin was combined with DIP. Using human testicular carcinoma in the same model, complete tumor regression was achieved (14). Barberi-Heyob et al. (15) found that DIP synergistically increased the growth-inhibitory activity of cisplatin in MCF-7 human breast cancer cells. Perussi et al. (16) have studied the potentiation of cisplatin cytotoxicity by DIP in two human breast cancer cells, one of them cisplatin sensitive (MDA/ $\mathrm{S})$ and the other cisplatin resistant (MDA/ $\mathrm{R})$. In the presence of $30 \mu \mathrm{M} \mathrm{DIP}$, the $\mathrm{IC}_{50}$ of cisplatin was reduced by $39 \%$ for both cell lines. In the MDA/S cells, the cellular accumulation of cisplatin increased by $57 \pm 8 \%$ in the presence of $30 \mu \mathrm{M}$ DIP, which did not affect the accumulation of cisplatin in MDA/ $\mathrm{R}$. The cited investigators suggested that the enhancement of cisplatin cytotoxicity by DIP in MDA/S cells may be related to a DIPinduced increase in cisplatin accumulation, but the enhanced cytotoxicity in MDA/R cells employs a mechanism that does not involve an increase in the cellular accumulation of cisplatin.

In the present study we report the enhancement of cisplatin cytotoxicity by DIP in human larynx cancer cells (HEp-2) that is probably related to a DIP-induced increase in cisplatin accumulation.

\section{Material and Methods}

\section{Chemicals}

Cisplatin, cis-diaminedichloroplatinum
(II), and DIP, 2,6-bis (diethanolamine)-4,8dipiperidinopyrimido [5,4-d] pyrimidine were purchased from Sigma (St. Louis, MO, USA). Cisplatin stock solutions were made fresh $24 \mathrm{~h}$ before each experiment in unsupplemented medium to minimize the hydrolysis of cisplatin. Dipyridamole stock solutions were prepared in DMSO and kept in the dark at $4^{\circ} \mathrm{C}$. The maximum DMSO concentration used was $0.1 \%$. Drug solutions were sterilized via syringe filtration just before use. All chemicals were of analytical quality and were used as purchased.

\section{Cell culture}

HEp-2, a human larynx cancer cell line obtained from Adolfo Lutz Institute, São Paulo, SP, Brazil, was grown as a monolayer in $25-\mathrm{cm}^{2}$ flasks with Dulbecco's minimal essential medium supplemented with $10 \%$ fetal bovine serum, streptomycin and ampicillin at $37^{\circ} \mathrm{C}$ in a humidified atmosphere of $5 \% \mathrm{CO}_{2}$ in $95 \%$ air. Confluent cell cultures were harvested with Versene (a solution constituted mainly of $0.526 \mathrm{mM}$ EDTA) and removed from the flask with phosphate-buffered saline (PBS) solution. Cells were centrifuged, resuspended in medium and counted with a hemocytometer. Cell viability was assessed by the Trypan blue exclusion method.

\section{Cytotoxic assays}

HEp- 2 cells were seeded on Petri dishes at $4.10^{4}$ cells/dish and treated with $0,20,40$, 80,120 or $200 \mu \mathrm{M}$ cisplatin in unsupplemented medium, with or without a fixed concentration of DIP ranging from 0 to 35 $\mu \mathrm{M}$. It should be mentioned here that DIP is insoluble in aqueous solutions at concentrations above $40 \mu \mathrm{M}$. The cells were incubated with the drug(s) for $60 \mathrm{~min}$ at $37^{\circ} \mathrm{C}$ and $5 \%$ $\mathrm{CO}_{2}$. After drug removal ordinary supplemented medium was added and the cells were incubated for 3 days. The cells were 
harvested with Trypsin, fixed in $37 \%$ formaldehyde and counted using a hemocytometer. All experiments were carried out in duplicate. The number of cells for $0.0 \mu \mathrm{M}$ cisplatin and $0.0 \mu \mathrm{M}$ DIP was taken as the control, corresponding to $100 \%$ cell survival. An index of survival was calculated at each cisplatin concentration, i.e., the number of live cells with the drug divided by the number of control live cells without the drug. Median effect analysis was used to determine the mean inhibitory concentration $\left(\mathrm{IC}_{50}\right)$ for cisplatin and for DIP (17). Data were visualized graphically by plotting the index of cell survival against the cisplatin concentration. The degree of synergism between cisplatin and DIP was determined by using combination index analysis at a non-constant ratio as described above. According to Chou and Talalay (18), combination index $<1$ stands for synergism while combination in$\operatorname{dex}=1$ indicates summation and combination index $>1$ suggests antagonism (18).

Data are reported as means $\pm \mathrm{SD}$. The Student unpaired $t$-test was used to determine differences between pairs of means, with the level of significance set at $\mathrm{P}<0.05$.

\section{Determination of cisplatin accumulation in the presence of dipyridamole}

The method used to calculate the accumulation of cisplatin has been described (19). Briefly, cells were seeded into $60-\mathrm{mm}$ plastic culture dishes and grown to confluence as monolayers in ordinary supplemented medium at $37^{\circ} \mathrm{C}$ and $5 \% \mathrm{CO}_{2}$. The cells were incubated with $200 \mu \mathrm{M}$ cisplatin in the presence of $0,5,10,20$ or $30 \mu \mathrm{M}$ DIP in unsupplemented medium for $60 \mathrm{~min}$ at $37^{\circ} \mathrm{C}$, then washed four times with ice-cold PBS. Next, $1.0 \mathrm{ml}$ of $0.1 \%$ Triton X-100 in $0.1 \mathrm{~N} \mathrm{HCl}$ was added to each dish and the cells were scraped from the bottom surface. The detached cells were frozen in cryogenic vials for at least $24 \mathrm{~h}$. Upon thawing, the cells were sonicated at 7 watts for $15 \mathrm{~s}$. Twenty- microliter aliquots of the lysate were used for platinum analysis with a Perkin-Elmer Zeeman Atomic Absorption Spectrometer Model 4110ZL (Wellesley, MA, USA). Cisplatin accumulation is reported as pmol of platinum $/ \mathrm{mg}$ protein. The protein content of each sample was measured by the method of Lowry et al. (20). One-way analysis of variance (ANOVA) was used to analyze the atomic absorption data.

\section{Determination of the association constant of dipyridamole with the cell membrane}

The determination of the association constant of DIP with the cell membrane was performed by titration. The cells in a highdensity cell suspension were lysed by sonication or by adding a hypotonic solution and centrifuged. The protein concentration of the supernatant and membrane fraction was determined by the method of Lowry et al. (20). DIP solution $(1 \mu \mathrm{M})$ was added to variable concentrations of membrane suspensions ( 0 to $1.30 \mathrm{mg}$ of protein $/ \mathrm{ml}$ ), the samples were mixed in a Vortex mixer and incubated for $60 \mathrm{~min}$ at $37^{\circ} \mathrm{C}$ and $5 \% \mathrm{CO}_{2}$. The samples were then centrifuged at $4000 \mathrm{~g}$ for $10 \mathrm{~min}$ and the fluorescence spectra of the supernatant were obtained. The pellet obtained by centrifugation was washed twice with $1 \%$ phosphate buffer and solubilized in $1 \mathrm{ml}$ of $2 \%$ Triton $\mathrm{X}-100$ and $10 \% \mathrm{NaCl}$. The supernatant contains the cytoplasmic constituents and the pellet contains the mitochondria as well as nuclear and cell membranes. The fluorescence of the solubilized pellet and the supernatant was detected with a Hitachi F-4500 fluorometer (Ibaraki, Japan) in the region of 400-600 $\mathrm{nm}$ with excitation at $415 \mathrm{~nm}$ since DIP absorbs at this wavelength. A 1- $\mu$ M DIP solution was used as a standard for fluorescence intensity. Data from the titration were analyzed by directly fitting to the law of mass action $(21,22)$ or as double reciprocal plots of fluorescence intensity changes $(\Delta \mathrm{F})$ and membrane concentrations. 
Considering the equilibrium:

$\mathrm{D}+\mathrm{M} \Leftrightarrow \mathrm{D}-\mathrm{M}$

(Eq. 1)

where $\mathrm{D}$ represents the drug and $\mathrm{M}$ the cell membrane, the total fluorescence observed is due to the free and bound species of D. $\Delta \mathrm{F}$ represents the difference between the initial fluorescence intensity $\left(\mathrm{F}_{0}\right)$ in the absence of the cell membrane and the fluorescence intensity of the drug in the presence of cell membrane $(\mathrm{F})$. This difference $(\Delta \mathrm{F})$ is related to the quantity of the drug associated with the membrane. In order to quantitate the association constant for the binding of DIP to the membrane $\left(K_{\mathrm{b}}\right)$ and $\Delta \mathrm{F}_{\max }$, the fluorescence data for the supernatant obtained by titration of the drug with membrane suspensions were treated by the double reciprocal method $(23,24)$. This treatment is based on the following equation:

$$
\frac{1}{\Delta \mathrm{F}}=\frac{1}{\Delta \mathrm{F}_{\max }}+\frac{1}{\Delta \mathrm{F}_{\max }} \times \frac{1}{K_{\mathrm{b}}} \times \frac{1}{[\mathrm{M}]}
$$

where $\Delta \mathrm{F}_{\text {max }}$ is the variation of fluorescence intensity between the fluorescence intensity in the absence of the membrane and the

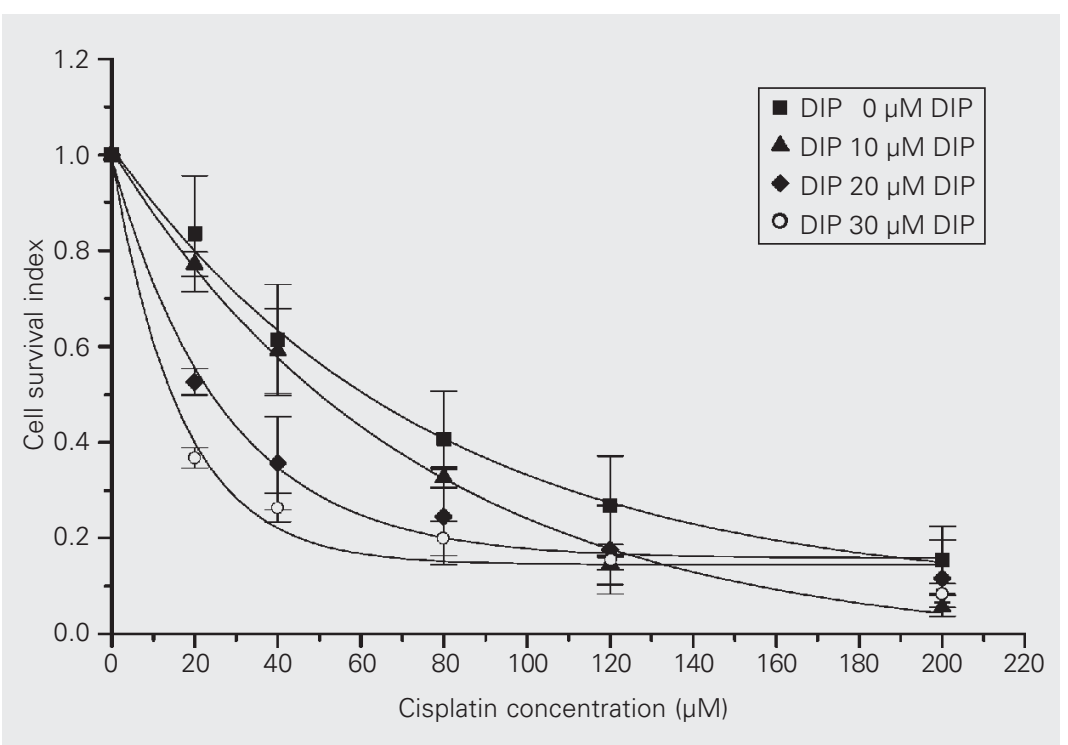

Figure 1. Survival index of HEp-2 cells as a function of cisplatin concentration in combination with dipyridamole (DIP). Cells were treated with several cisplatin concentrations $(0,20,40$, $80,120$ and $200 \mu \mathrm{M})$ combined with fixed DIP concentrations $(0,10,20$ and $30 \mu \mathrm{M})$ for $1 \mathrm{~h}$ at $37^{\circ} \mathrm{C}$ in the presence of $5 \% \mathrm{CO}_{2}$. Data are reported as means \pm SD for 5-13 replicates. fluorescence emission intensity of the drug at a saturation membrane concentration (based on the membrane protein concentration). This value can be obtained from the fit of the experimental data using Equation 2.

\section{Investigation of complex formation between dipyridamole and cisplatin}

The possibility of a direct interaction between DIP and cisplatin was investigated by determining the suppression of the fluorescence of $5 \mu \mathrm{M}$ DIP after each addition of $20 \mu 1$ of a $2 \mathrm{mM}$ cisplatin solution prepared in phosphate buffer, $\mathrm{pH}$ 7.2. The fluorescence spectrum of each sample was obtained from 425 to $600 \mathrm{~nm}$ with a Hitachi F-4500 fluorometer, with excitation at $415 \mathrm{~nm}$. Sample absorbance was monitored after each addition of the titrating compound and the spectra from 250 to $600 \mathrm{~nm}$ were recorded with a Shimadzu UV-1601 PC spectrophotometer.

\section{Results and Discussion}

Figure 1 shows the indices of cell survival for HEp-2 cells as a function of cisplatin concentration, in the absence and presence of 10,20 and $30 \mu \mathrm{M}$ DIP. At each cisplatin concentration, the indices of survival of the cells were reduced in the presence of DIP. In this cell line, the survival curve for cisplatin alone was significantly different from that for cisplatin plus DIP $(\mathrm{P}<$ $0.001)$. These results suggest that the cytotoxicity of cisplatin is increased in the presence of DIP. Table 1 presents the $\mathrm{IC}_{50}$ values obtained from plots shown in Figure 1. In HEp-2 cells, the $\mathrm{IC}_{50}$ of cisplatin was reduced by 25,60 and $82 \%$ in the presence of 10, 20 and $30 \mu \mathrm{M}$ DIP, respectively. The degree of enhancement of cisplatin cytotoxicity increased with DIP concentration. Perussi et al. (16) observed that the $\mathrm{IC}_{50}$ value for cisplatin in human breast cancer cells sensitive to cisplatin (MDA/S) de- 
creased by $39 \%$ in the presence of $30 \mu \mathrm{M}$ DIP, suggesting that HEp-2 cells are more sensitive to the combination of the drugs.

Figure 2 shows the sensitivity of the cells to DIP alone. DIP alone decreased the survival of HEp-2 cells by 10,17 and $29 \%$ at concentrations of 10,20 and $30 \mu \mathrm{M}$, respectively. This reduction was statistically significant $(\mathrm{P}<0.01)$ for 20 and $30 \mu \mathrm{M}$ DIP. The $\mathrm{IC}_{50}$ of DIP was estimated to be $94 \pm 10$ $\mu \mathrm{M}$ since the solubility of DIP is very low in aqueous solutions and just a short range of DIP concentrations could be used in the assay ( 0 to $35 \mu \mathrm{M}$ DIP). The cytotoxic effect of cisplatin was 1.6 times more potent than that of DIP alone in these cells ( $\mathrm{IC}_{50}$ was 94 $\mu \mathrm{M}$ for DIP and $60 \mu \mathrm{M}$ for cisplatin).

Table 2 presents the affected fractions and the combination index obtained for the cytotoxic experiments performed at a nonconstant ratio with cisplatin in combination with DIP in HEp-2 cells. Combination index analysis indicated that this parameter was lower than one in $93 \%$ of the combinations used, suggesting that the interaction between cisplatin and DIP is synergistic (18). Similar results of synergistic interaction were reported by Jekunen et al. (13) for an ovarian carcinoma cell line treated with the combination of these two drugs.

The data in Figure 1 suggest that the fraction affected by $80 \mu \mathrm{M}$ cisplatin with 10 $\mu \mathrm{M}$ DIP was similar to the fraction affected by $40 \mu \mathrm{M}$ cisplatin with $20 \mu \mathrm{M}$ DIP and 20 $\mu \mathrm{M}$ cisplatin with $30 \mu \mathrm{M}$ DIP. However, the indices obtained for these drug combinations were different (Table 2), suggesting that the interaction of cisplatin with DIP was synergistic when low cisplatin concentrations were combined with moderate and high DIP concentrations, and moderately synergistic when low cisplatin concentrations were combined with low DIP concentrations. Furthermore, Figure 1 indicates that the fraction affected by $120 \mu \mathrm{M}$ cisplatin with $10 \mu \mathrm{M}$ DIP may be similar to the fractions affected by $120 \mu \mathrm{M}$ cisplatin with $20 \mu \mathrm{M}$ DIP and by
$120 \mu \mathrm{M}$ cisplatin with $30 \mu \mathrm{M}$ DIP. The indices obtained for these drug combinations (Table 2) were about the same, suggesting that the interaction of cisplatin with DIP was also synergistic at high cisplatin concentrations.

Table 1. Effect of dipyridamole on the cytotoxicity of cisplatin in the human larynx HEp-2 cell line.

\begin{tabular}{ccc}
\hline $\begin{array}{l}\text { Dipyridamole } \\
(\mu \mathrm{M})\end{array}$ & $\mathrm{IC}_{50}(\mu \mathrm{M})$ & $\begin{array}{c}\text { Decrease in } \\
\text { the } \mathrm{IC}_{50}(\%)\end{array}$ \\
\hline 0 & $60 \pm 9$ & - \\
10 & $45 \pm 2$ & 25 \\
20 & $24 \pm 2$ & 60 \\
30 & $11 \pm 3$ & 82 \\
\hline
\end{tabular}

The cells were exposed to several cisplatin concentrations $(0,20,40,80,120$ and $200 \mu \mathrm{M})$ with and without dipyridamole for $1 \mathrm{~h}$ at $37^{\circ} \mathrm{C}(\mathrm{N}=5$ 13). Data are reported as means $\pm S D$. The $I C_{50}$ values for the association of the drugs were statistically different $(P<0.05$; ANOVA).

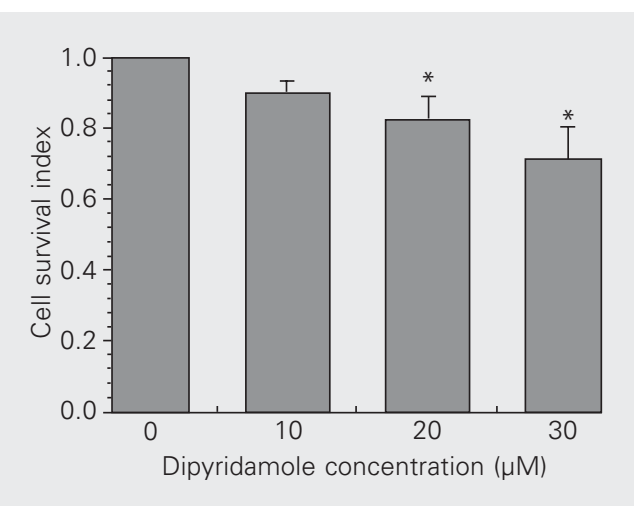

Figure 2. Effect of dipyridamole (DIP) on the survival index of HEp-2 cells. Cells were treated with several DIP concentrations $(0,5,10,15,20$ and 30 $\mu \mathrm{M})$ for $1 \mathrm{~h}$ at $37^{\circ} \mathrm{C}$ in the presence of $5 \% \mathrm{CO}_{2}$. Each column represents the mean $\pm \mathrm{SD}$ for two experiments each performed in duplicate. ${ }^{*} P<0.005$ compared to no DIP (ANOVA).

Table 2. Combination indexes for cisplatin and dipyridamole (DIP) in the HEp-2 cell line obtained by the median effect analysis.

\begin{tabular}{|c|c|c|c|c|c|c|}
\hline \multirow[t]{3}{*}{ Cisplatin $(\mu \mathrm{M})$} & \multicolumn{6}{|c|}{ DIP concentration $(\mu \mathrm{M})$} \\
\hline & \multicolumn{2}{|c|}{10} & \multicolumn{2}{|c|}{20} & \multicolumn{2}{|c|}{30} \\
\hline & $f_{a}$ & $\mathrm{Cl}$ & $f_{a}$ & $\mathrm{Cl}$ & $f_{a}$ & $\mathrm{Cl}$ \\
\hline 20 & 0.23 & 1.17 & 0.47 & 0.64 & 0.62 & 0.46 \\
\hline 40 & 0.49 & 0.83 & 0.64 & 0.60 & 0.74 & 0.46 \\
\hline 80 & 0.66 & 0.85 & 0.75 & 0.73 & 0.80 & 0.58 \\
\hline 120 & 0.84 & 0.66 & 0.82 & 0.75 & 0.86 & 0.66 \\
\hline 200 & 0.96 & 0.55 & 0.88 & 0.92 & 0.92 & 0.75 \\
\hline
\end{tabular}

Data are reported as means $\pm S D$ for $5-13$ replicates. $\mathrm{Cl}=$ combination index; $\mathrm{f}_{\mathrm{a}}=$ affected fraction. 
In order to assess the mechanism involved in the synergism between cisplatin and DIP, cellular accumulation of cisplatin was determined in the presence of DIP. Table 3 shows that at $0.0 \mu \mathrm{M}$ DIP the accumulation of cisplatin in HEp-2 cells was $830 \pm 400$ pmol $\mathrm{Pt} / \mathrm{mg}$ membrane protein and this value increased with increasing DIP concentrations from 0 to $30 \mu \mathrm{M}$. In the presence of $30 \mu \mathrm{M}$ DIP, the cisplatin accumulation increased significantly by $65 \%$ to $1373 \pm 400 \mathrm{pmol} \mathrm{Pt} /$ mg protein $(\mathrm{P}<0.005)$, while the $\mathrm{IC}_{50}$ value for cisplatin combined with $30 \mu \mathrm{M}$ DIP decreased by $82 \%$. These results suggest that

Table 3. Effect of dipyridamole (DIP) on the accumulation of cisplatin in human larynx HEp-2 tumor cells.

\begin{tabular}{ccc}
\hline $\begin{array}{l}\text { Dipyridamole } \\
(\mu \mathrm{M})\end{array}$ & $\begin{array}{c}\text { pmol Pt/mg } \\
\text { protein }\end{array}$ & $\begin{array}{c}\text { Increase in } \\
\mathrm{Pt}(\%)\end{array}$ \\
\hline 0 & $830 \pm 400$ & 0 \\
10 & $934 \pm 470$ & 13.0 \\
20 & $1053 \pm 500$ & 27.0 \\
30 & $1373 \pm 401$ & 65.0
\end{tabular}

All cells were treated with $200 \mu \mathrm{M}$ cisplatin for $1 \mathrm{~h}$ at $37^{\circ} \mathrm{C}$ in combination with DIP $(0,10,20$ and 30 $\mu \mathrm{M})$. Data are reported as means \pm SD for 5 replicates. Platinum $(\mathrm{Pt}$ ) content for the association of $30 \mu \mathrm{M}$ DIP is statistically different from that of cisplatin itself $(P<0.005$; ANOVA)

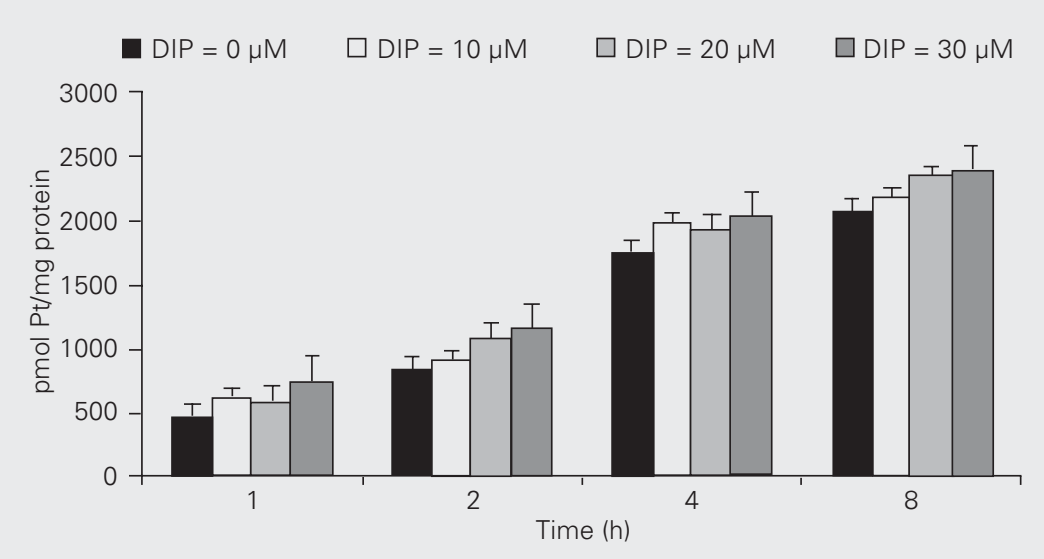

Figure 3. Effect of dipyridamole (DIP) and incubation time on intracellular accumulation of cisplatin in the human larynx tumor cell line $\mathrm{HEp}-2$ at $37^{\circ} \mathrm{C}$ and $5 \% \mathrm{CO}_{2}$. Data are reported as means \pm SD for 5 replicates. Platinum (Pt) content for each incubation time was statistically different $(P<0.005)$ from that of $1 \mathrm{~h}$ of incubation. the increase in cisplatin accumulation by DIP increased the cytotoxicity of cisplatin in HEp-2 cells.

Experiments were performed to investigate the effect of incubation time on the intracellular accumulation of cisplatin in HEp-2 cells. When cisplatin was combined with DIP $(0,10,20$ and $30 \mu \mathrm{M})$ (Figure 3) the increase in incubation time of the drugs was found to lead to an increase in intracellular cisplatin concentration. For each incubation time used there was a significant increase $(\mathrm{P}<0.005$, ANOVA) in platinum accumulation. So, we may conclude from these results that the amount of intracellular cisplatin depends on DIP concentration as well as on the duration of incubation with the drugs.

Titrations of membrane suspensions have indicated that the association depends on the increase of the membrane concentration in solution. The results were closely similar to those obtained for the interaction of DIP with mitochondrial and erythrocyte membranes $(21,22)$. As the membrane concentration increased, the fluorescence intensity in the supernatant decreased, while it increased in the pellet. These alterations in the emission spectra were used to estimate the association constant for DIP with the cell membrane.

A plot of $1 / \Delta \mathrm{F}$ (data for the supernatant fluorescence which was proportional to free DIP concentration) as a function of $1 /[\mathrm{M}]$ may be used to obtain $K_{\mathrm{b}}$, the binding constant. The results obtained for both treatments, the mass-action law and the method of double reciprocal plot, are shown in Figure 4 . The $K_{\mathrm{b}}$ value obtained by the double reciprocal plot was $0.36 \pm 0.12$ (mg protein/ $\mathrm{ml})^{-1}$. This value was obtained as the ratio of the intercept to the slope in the linear fit shown in the insert in Figure 4 and $\Delta \mathrm{F}_{\max }$ was obtained from the reciprocal of the intercept value. This value for the binding constant was quite similar to those obtained for the association constant of DIP with the erythro- 
cyte ghost membranes of $0.40 \pm 0.02$ $(\mathrm{mg} \text { protein } / \mathrm{ml})^{-1}(22)$ and for the association constant of DIP with the mitochondrial membrane of $0.8 \pm 0.1(\mathrm{mg} \text { protein } / \mathrm{ml})^{-1}$ (21). On the basis of the dependence of the DIP fraction in the pellet on membrane concentration, we found that $36 \%$ of the drug was present in the pellet. This means that with $1 \mu \mathrm{M}$ DIP concentration and an excess of membrane, about $36 \%$ of the drug was bound. This value is quite close to the maximum DIP saturation of $47 \%$ reported for the mitochondrial membrane (21).

Borges et al. (25) studied the interaction of DIP with bovine serum albumin (BSA) and membrane model systems (micelles). It was shown that DIP binds strongly to BSA, in agreement with the high level of DIP binding to human plasma albumin. This study (25) also showed that DIP binds more strongly to neutral micelles and the results of fluorescence suppression suggest that DIP is located in the interface of the micelle, close to the beginning of the hydrophobic region. In fact, DIP incorporation seemed to occur in a region close to the border of the hydrophobic and polar parts of a phospholipid monolayer (26). It has been shown that the protective effect of DIP against the lipid peroxidation caused by cumene hydroperoxide in mitochondrial membrane was strongly dependent on the duration of incubation with the drug prior to the addition of the oxidant (27). A similar feature was observed for the protective effect of DIP on red blood cell lysis. The protection was quite sensitive to the time of incubation with the drug and to its concentration (22).

The experiments of fluorescence suppression were performed in order to determine the complex formation between DIP and cisplatin. The fluorescence at $480 \mathrm{~nm}$ of a $10 \mu \mathrm{M}$ DIP solution in $0.02 \mathrm{M}$ phosphate buffer, $\mathrm{pH}$ 7.2, was monitored after each addition of cisplatin (0 to $0.4 \mathrm{mM}$ final cisplatin concentration). The Stern-Volmer plot (data not shown) resulted in a straight line parallel to the $\mathrm{x}$-axis in the entire range of the suppressor concentration used. Thus, the Stern-Volmer constant $\left(K_{\mathrm{SV}}\right)$ could not be obtained in this case because there was no fluorescence suppression, indicating that no complexation occurred between DIP and cisplatin at the concentrations used.

The present study has demonstrated that the combination of cisplatin and DIP leads to an increased cytotoxicity in HEp-2 cells. A reduction of up to $82 \%$ in the $\mathrm{IC}_{50}$ of cisplatin was obtained when cisplatin was combined with $30 \mu \mathrm{M}$ DIP. This reduction was much greater than that observed in other cell lines, such as in cisplatin-sensitive and cisplatin-resistant breast tumor cell lines previously studied by us (16). In that investigation, in the presence of $30 \mu \mathrm{M}$ DIP, the $\mathrm{IC}_{50}$ of cisplatin was reduced just by $39 \%$ for both cell lines. This result suggests that the combination of these drugs can also improve the cytotoxicity of cisplatin in resistant cell lines. The results of that study as well as others in the literature (13) permit us to conclude that the co-administration of cisplatin and DIP is feasible and may permit the treatment of

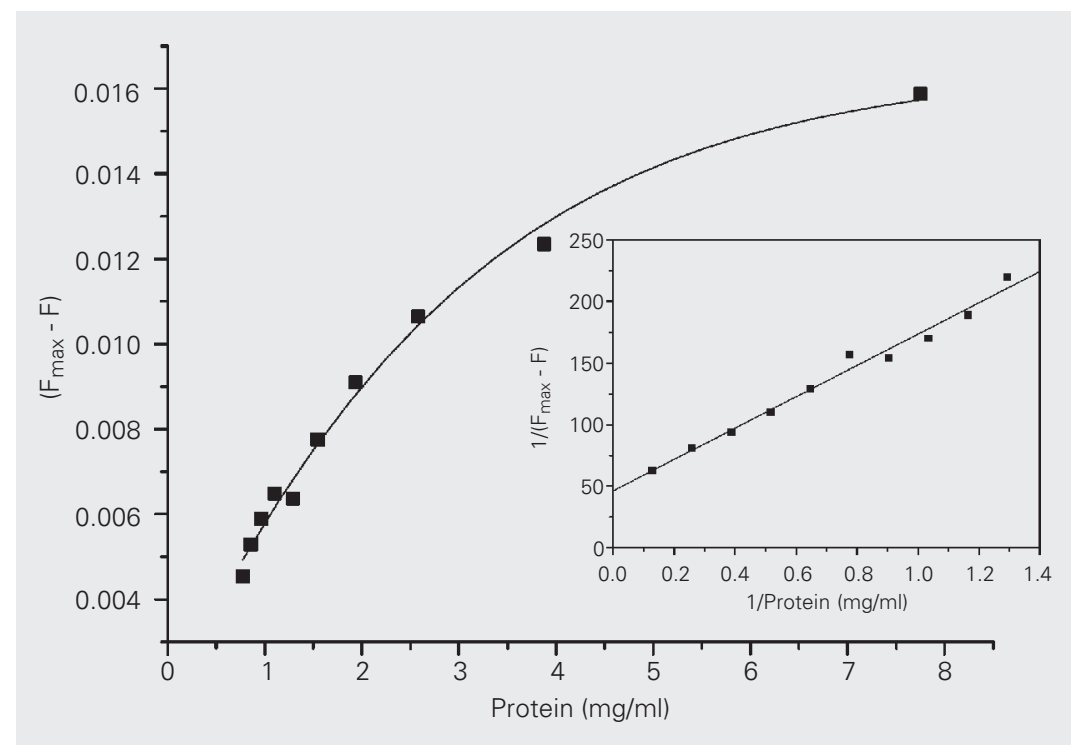

Figure 4. Analysis of the titration of dipyridamole (DIP) with HEp-2 cell membrane by fluorescence for the calculation of the association constant. Inset: Double reciprocal plot of the change in DIP fluorescence emission vs 1/protein. DIP concentration of $1 \mu \mathrm{M}$, excitation at $415 \mathrm{~nm}$ and emission at $495 \mathrm{~nm}$. 
cancer patients with cisplatin concentrations that are effective in killing cisplatin-resistant cancer cells by reducing or eliminating the severe side effects of high drug concentrations. In this way, resistance to cisplatin may be overcome.

The atomic absorption experiments showed that DIP increases the uptake of cisplatin by cells in a concentration-dependent manner. These results agree with those reported by Perussi et al. (16) and by Jekunen et al. (13) who observed an increased accumulation of cisplatin due to DIP, but without increasing Trypan blue or propidium iodide uptake or changing cell size. The cited investigators concluded that the DIP-induced increase in cisplatin accumulation was not associated with a nonspecific increase in membrane permeability. In the present study we showed that the cellular accumulation of cisplatin is concentration and time dependent. It has been shown that DIP incorporation into model membranes is time dependent $(27,22)$.

The analysis of the median effect showed that the interaction between these two drugs was synergistic and our fluorescence sup- pression experiments showed no complexation between DIP and cisplatin. Fluorescence experiments also allowed to determine the binding constant of DIP to the cell membrane as $0.36 \pm 0.12(\mathrm{mg} \text { protein } / \mathrm{ml})^{-1}$, a value similar to those obtained for the binding of this drug to mitochondrial and red blood cell membranes.

Our results suggest that the enhancement of cisplatin cytotoxicity by DIP in HEp-2 cells may be related to a DIP-induced increase in cisplatin accumulation. The results obtained support the importance of combined therapy to reduce the doses of chemotherapeutic drugs and therefore the side effects of chemotherapy.

\section{Acknowledgments}

The authors would like to thank Dr. Marcel Tabak (Instituto de Química de São Carlos, USP, São Carlos, SP, Brazil) for valuable suggestions and to Dr. Robert G. Canada (Howard University College of Medicine, Washington DC, USA) for a critical reading of the manuscript.

\section{References}

1. Zenker A, Galanski M, Bereuter L, Bernhard KK \& Kinder W (1999). Capillary electrophoretic study of cisplatin interaction with nucleoside monophosphates, di- and trinucleotides. Journal of Chromatography. $A$, 852: 337-346.

2. Zamble DB \& Lippard SJ (1995). Cisplatin and DNA repair in cancer chemotherapy. Trends in Biochemical Sciences, 20: 435-439.

3. Pillaire MJ, Hoffmann JS, Defais M \& Villani G (1995). Replication of DNA containing lesions and its mutagenic consequences. Biochimie, 77: 803-807.

4. Fitzgerald GA (1987). Dipyridamole. New England Journal of Medicine, 316: 1247-1257.

5. Iuliano L, Pedersen JZ, Ferro D \& Violi F (1995). A potent chainbreaking antioxidant activity of the cardiovascular drug dipyridamole. Free Radical Biology and Medicine, 18: 239-247.

6. Plagemann PGW, Wohlhueter RM \& Woffendin C (1988). Nucleoside and nucleoside transport in animal cells. Biochimica et Biophysica Acta, 947: 405-443.

7. Grem JL \& Fisher PH (1989). Enhancement of 5-fluorouracil anticancer activity by dipyridamole. Pharmacology and Therapeutics, 40: 349-371.
8. Cabral S, Leis S, Bover L, Nembrot M \& Mordoh J (1984). Dipyridamole inhibits reversion by thymidine of methotrexate effect and increases drug uptake in sarcoma 180 cells. Proceedings of the National Academy of Sciences, USA, 81: 3200-3203.

9. Fisher PH, Pamukcu R, Bittner G \& Willson JKV (1984). Enhancement of the sensitivity of human colon cancer cells to growth inhibition by acivicin achieved through inhibition of nucleic acid precursor salvage by dipyridamole. Cancer Research, 44: 33553359.

10. Kusumoto $F$, Maehara $Y$, Anai $H$, Kusumoto $T$ \& Sugima-Chi $K$ (1988). Potentiation of adriamycin cytotoxicity by dipyridamole against HeLa cells in vitro and sarcoma 180 cells in vivo. Cancer Research, 48: 1208-1212.

11. Turner RN \& Curtin NJ (1996). Dipyridamole increases inhibition, accumulation and retention in parental and multidrug-resistant $\mathrm{CHO}$ cells. British Journal of Cancer, 73: 856-860.

12. Howell SB, Hom D, Sanga R, Vick J \& Aramson IS (1989). Comparison of the synergistic potentiation of etoposide, doxorubicin, and vinblastine cytotoxicity by dipyridamole. Cancer Research, 49: 31783183. 
13. Jekunen A, Vick J, Sanga R, Chan CK \& Howell SB (1992). Synergism between dipyridamole and cisplatin in human ovarian carcinoma cells in vitro. Cancer Research, 52: 3566-3571.

14. Keane TE, Rosner G, Donaldson JT, Norwood DL, Poulton SH \& Walther PJ (1990). Dipyridamole-cisplatin potentiation: enhanced in vivo cytotoxic in xenograft models of human testicular and bladder cancers. Journal of Urology, 144: 1004-1009.

15. Barberi-Heyob M, Griffon G, Merlin JL \& Weber B (1993). Sequence-dependent growth-inhibitory effects of the in vitro combination of fluorouracil cisplatin and dipyridamole. Cancer Chemotherapy and Pharmacology, 33: 163-170.

16. Perussi JR, Paltoo DN, Toppin VAL \& Canada RG (2003). Synergism between dipyridamole and cisplatin in human breast cancer cells in vitro. Química Nova, 26: 340-343.

17. Chou TC \& Hayball M (1996). CalcuSyn: Windows Software for Dose Effect Analysis. Biosoft, Cambridge, UK.

18. Chou TC \& Talalay P (1984). Quantitative analysis of dose-effect relationships: the combined effects of multiple drugs or enzyme inhibitors. Advances in Enzyme Regulation, 22: 27-55.

19. Mack KM, Canada RG \& Andrews PA (1997). The effects of terbium on the cellular accumulation of cisplatin in MDA-MB-231 human breast tumor cells. Cancer Chemotherapy and Pharmacology, 39: 217-222.

20. Lowry OH, Rosebrough NJ, Farr AL \& Randall RJ (1951). Protein measurement with the Folin phenol reagent. Journal of Biological Chemistry, 193: 265-275.

21. Nepomuceno MF, Mamede MEO, Macedo DV, Alves AA, Pereira-
da-Silva L \& Tabak M (1999). Antioxidant effect of dipyridamole and its derivative RA-25 in mitochondria: correlation of activity and location in the membrane. Biochimica et Biophysica Acta, 1418: 285294.

22. Ruggiero AC, Nepomuceno MF, Jacob RF, Dorta DJ \& Tabak M (2000). Antioxidant effect of dipyridamole (DIP) and its derivative RA 25 upon lipid peroxidation and hemolysis in red blood cells. Physiological Chemistry and Physics and Medical NMR, 32: 35-48.

23. Borissevitch IE, Borges CPF, Borissevitch GP, Yushmanov VE, Louro SRW \& Tabak M (1996). Binding and location of dipyridamole derivatives in micelles: the role of drug molecular structure and charge. Zeitschrift für Naturforschung, 51: 578-590.

24. Tabak M \& Borissevitch IE (1992). Interaction of dipyridamole with micelles of lysophosphatidylcholine and with bovine serum albumin: fluorescence studies. Biochimica et Biophysica Acta, 1116: 241-249.

25. Borges CPF, Honda S, Berlinck RGS, Imasato H, Berci Filho P \& Tabak M (1995). Synthesis, characterization and interaction with ionic micelles of tetraacetylated dipyridamole. Spectrochimica Acta (Part A), 51: 2575-2584.

26. Borissevitch GP, Tabak M \& Oliveira ON (1996). Interaction of dipyridamole with lipids in mixed Langmuir monolayers. Biochimica et Biophysica Acta, 1278: 12-18.

27. Nepomuceno MF, Alonso A, Pereira-da-Silva L \& Tabak M (1997). Inhibitory effect of dipyridamole and its derivatives on lipid peroxidation in mitochondria. Free Radical Biology and Medicine, 23: 1046-1054. 